\title{
Quality Characteristics of Kochujang Prepared with Peach Jam and Salt Replacement
}

\section{Kyung-Mi Jung1 1 , Sun-Hwa Kim²,3, Eun-Chul Seo', Sanjeev Kumar Dhungana4, II-Doo Kim ${ }^{5}$}

\author{
${ }^{1}$ Cheongdo Peach Research Institute, GyeongSangBuk-Do Agricultural Technology Administration, Cheongdo \\ 38315, Korea \\ ${ }^{2}$ KMF Co., Ltd., Daegu 41065, Korea \\ ${ }^{3}$ Department of Food Science and Technology, Keimyung University, Daegu 42403, Korea \\ ${ }^{4}$ School of Applied Biosciences, Kyungpook National University, Daegu 41566, Korea \\ ${ }^{5}$ International Institute of Agricultural Research and Development, Kyungpook National University, Daegu 41566, \\ Korea
}

\begin{abstract}
Kochujang, hot pepper paste, is a widely consumed Korean traditional food and also makes a typical Korean meal. The objective of the present study was to investigate the quality characteristics of kochujang prepared with salt replacement (SR) as a substitute of ordinary salt (OS) since intake of high sodium is not good for health. Reducing sugar (29.35\%) and amino nitrogen (82.6\%) contents of SR kochujang were significantly high compared to OS kochujang (24.82 and $68.6 \%$, respectively), however, sodium content was significantly lower in SR kochujang (1292.26 mg/100 g) than in OS kochujang $(1568.71 \mathrm{mg} / 100 \mathrm{~g})$. Free sugars like fructose and glucose contents were also significantly high in SR kochujang. Similarly, antioxidant potentials in terms of DPPH and ABTS were significantly high for SR kochujang (30.13 and 27.31\%) compared to OS kochujang (27.05 and $24.72 \%$ ), respectively. In addition, the score for overall acceptance of SR kochujang (4.81) was higher than that of OS kochujang (3.13). Results of the present study suggested that nutritious kochujang having significantly higher antioxidant potentials and lower sodium content could be prepared using salt replacement as a substitute of ordinary salt.
\end{abstract}

Keywords: Kochujang, Peach Jam, Quality Characteristics, Salt Replacement, Sodium

\section{Introduction}

Kochujang, hot pepper paste is a Korean traditional food (Lee, 1979) with a sweet and palatable taste that is prepared by fermentation of glutinous rice with red pepper powder, mеju and salt. It has been widely used in Korean people's daily meals. It is the fourth and most enjoyed traditional food component that makes a typical Korean meal (Kwon et al., 2015). As mentioned in the previous report (Kwon et al., 2014) kochujang, along with kimchi, another fermented traditional food is one of the most symbolic fermented food of Korea (Shin et al., 2011). Westernization of Korean lifestyles and the increasing tendency to nuclear family have influenced the use of improved factory made kochujang rather than traditional one. Kochujang quality is determined by the type and ratio of ingredients in the mixture (Cho et al., 1981; Kim et al., 2008), microbial strain (Oh et al., 2000), and the proportion of salt (Kim and Yang, 2004).

The studies on kochujang have been concentrated basically on the different starch sources (Moon and Kim, 1988; Shin et al., 1997) used in its preparation, and followed by addition of different secondary ingredients such as fig (Kim and Song, 2002), Japanese apricot (Lee, 2008), and red koji (Hyun et al., 2007) to improve the quality or to alter its physicochemical properties during fermentation and/or aging processes. In addition, to enhance the quality of kochujang so as to make it a global seasoning, low-salt kochujang is desirable in order to decrease the consumption of sodium. However, the concentration of salt influences (Oh et al., 2002) the fermentation and aging of kochujang, for instance if the proportion of salt is low, the fermentation during aging and/or during storage might not take place appropriately. Yamamoto et al. (1984) reported that if

This article is published under the terms of the Creative Commons Attribution License 4.0

Author(s) retain the copyright of this article. Publication rights with Alkhaer Publications.

Published at: http://www.ijsciences.com/pub/issue/2017-07/

DOI: 10.18483/ijSci.1359; Online ISSN: 2305-3925; Print ISSN: 2410-4477 
alcohol is used in the preparation of kochujang, the unfavorable activities of microorganisms could well be controlled during aging as well as storage and thus low-salt kochujang could be prepared. There are other reports on kochujang about addition of spices like garlic (Kim and Lee, 2001), mustard and horseradish (Shin et al., 2000; Oh et al., 2006) and also the mixtures of these anti-microbial materials (Kim, 2005; Park and Kim, 2007) during its preparation.

Kochujang is a sweet-hot-salty seasoning with good nutrient composition. However, high intake of sodium may cause elevated osmotic pressure of extracellular fluid, increased blood sodium, and aggravation of heart and kidney's burden, leading to high blood pressure and heart diseases (Meneton et al., 2005). Researches have been conducted to replace the concentration of ordinary salt in kochujang. For instance, Kim (2001) used antimicrobial alcohol, mustard, or chitosan as the substitute of a part of ordinary salt during kochujang preparation. Similarly, Seo et al. (2014) added various antimicrobial materials to the low-salt kochujang during preparation and at eight weeks of its aging. In the present study, half or whole of the ordinary salt in kochujang was substituted with 'salt replacement' which was prepared with fermented vegetables and unsterilized brown-rice vinegar.

\section{Materials and methods}

\section{Materials}

Hot pepper powder, grain syrup (Daesang, Seoul, Korea), glutinous rice powder, meju (Korean-style soybean koji), peach jam (Cheongdo Peach Research Institute, Cheongdo, Korea) and ordinary salt were purchased from local stores. Anhydrous ethanol was obtained from Duksan Pure Chemicals (Ansan, Kyunkido, Korea).

\section{Preparation of peach Kochujang}

Kochujang was prepared by gelatinizing a mixture of glutinous rice powder, hot pepper powder, grain syrup, meju, ethanol and peach jam. Ordinary salt and/or salt replacement was used to prepare kochujang samples. The samples containing 4\% ordinary salt, $2 \%$ ordinary salt and $2 \%$ salt replacement, and $4 \%$ salt replacement were named as PK-1, PK-2, and PK-3, respectively. The detail of ingredients are mentioned in Table 1.

Table 1. Formulae for peach kochujang prepared with different proportions of ordinary salt and salt replacement

\begin{tabular}{lccc}
\hline & & Sample $^{1)}$ \\
\cline { 2 - 4 } Ingredients (\%) & PK-1 & PK-2 & PK-3 \\
\hline Hot pepper powder & 15 & 15 & 15 \\
Grain syrup & 32 & 32 & 32 \\
Glutinous rice powder & 10 & 10 & 10 \\
Meju (Korean-style soybean koji) & 3 & 3 & 3 \\
Ethanol(Spirit) & 5 & 5 & 5 \\
Peach jam & 31 & 31 & 31 \\
Sun-dried salt & 4 & 2 & 0 \\
Salt replacement & 0 & 2 & 4 \\
\hline
\end{tabular}

${ }^{1)}$ PK-1: Kochujang containing 4\% ordinary salt, PK-2: Kochujang containing 2\% ordinary salt and $2 \%$ salt replacement, and PK-3: Kochujang containing 4\% salt replacement.

\section{Physicochemical parameters}

The pH of Kochujang was measured using a portable pH meter (Thermo Scientific, Orion Star A221, Waltham, Massachusetts, USA). Total acid (malic acid) was measured by adding $5 \mathrm{~g}$ of kochujang sample to $125 \mathrm{~mL}$ of deionized water and titrating with $0.1 \mathrm{~N}$ sodium hydroxide to an endpoint $\mathrm{pH}$ 8.2. The content of amino nitrogen was analyzed according to the formal titration method as described by AOAC (1984). The total reducing sugar was measured using DNS (Dinitrosalicylic acid) method (Ghose, 1987) at $540 \mathrm{~nm}$. To measure reducing sugar, $1.5 \mathrm{~mL}$ aliquot of the hydrolysate were sampled and centrifuged at $1660 \times \mathrm{g}$ for $10 \mathrm{~min}$, supernatant was filtered through a $0.2 \mu \mathrm{m}$ syringe filter.

\section{Sodium content}

Sodium content in the Kochujang was measured using chemical analysis and salinity measurement (Shin et al., 2014). The chemical analysis was conducted using an inductively coupled plasma optical emission spectrometer (IRIS II XSP; Thermo Scientic, USA). The salinity measurement was measured using salinometer (GMK-530; G-Won Hitech Co, Korea) as described by Lee (1997). 


\section{DPPH radical scavenging activity}

The radical scavenging potential of peach kochujang was measured using 1,1-diphenly-2-picrylhydrazyl (DPPH) according to the methods described by Blois (1958). One hundred microliters of $0.1 \% \mathrm{DPPH}$ methanol solution was mixed with $0.1 \mathrm{~mL}$ of sample. The mixture was allowed to react at room temperature in dark for $30 \mathrm{~min}$ and absorbance was measured at $517 \mathrm{~nm}$ (Multiskan GO Microplate Spectrophotometer; Thermo Fisher Scientific). The radical-scavenging activity (RSA) was calculated as a percentage inhibition using the following equation.

$\%$ inhibition $=(1-\mathrm{Sab} / \mathrm{Cab}) \times 100$

where, $\mathrm{Sab}$ is the absorbance of the sample and DPPH solution; Cab is absorbance of DPPH solution without sample.

\section{ABTS cation radical-scavenging assay}

The ABTS cation radical-scavenging assay was carried out following a previous report (Re et al., 1999). Briefly, stock solution was prepared by reacting $7 \mathrm{mM}$ ABTS with $2.45 \mathrm{mM}$ potassium persulfate to generate the ABTS cation chromophore. The mixture was diluted with absolute ethanol to give an absorbance of 1.5-2 at $414 \mathrm{~nm}$. An aliquot of the samples $(10-40 \mu \mathrm{L})$ was added to $3 \mathrm{~mL}$ of ABTS reagent and the absorbance was taken using an UV/visible spectrophotometer (Shidmazu UV-1601, Japan) after initial mixing and up to 90 min until it reached a plateau. Total antioxidant capacity was calculated relative to the reactivity of ascorbic acid as a standard under the same conditions.

\section{Quantification of free sugars}

Free sugar content was analyzed following the method of Génard and Souty (1996). The sample (5 g) was mixed with $10 \mathrm{~mL}$ of distilled water and homogenized. The volume of was adjusted to $20 \mathrm{~mL}$ by adding distilled water. The mixture was centrifuged at $16000 \times \mathrm{g}$ for $30 \mathrm{~min}$. The collected supernatant was filtered through a cartridge (Sep-Pak C18, WAT023501, Waters, USA) and a $0.45 \mu \mathrm{m}$ syringe filter (PVDF, Whatman, Tokyo, Japan). Free sugars were quantified by HPLC (Model 9300, Younglin Co., Anyang, Korea) consisting of a refractive index detector (Triathlon M730D, Younglin Co.), a column heater set at $85^{\circ} \mathrm{C}$, and Sugar-Pak $(6.5 \times 300 \mathrm{~mm}$, Alltech, Staten Island, NY, USA); the mobile phase was deionized-distilled $\mathrm{H}_{2} \mathrm{O}$ delivered at $0.5 \mathrm{~mL} / \mathrm{min}$. The glucose, fructose, sucrose, and maltose obtained from Aldrich Chemical Co. Inc. (Milwaukee, WI, USA), were used as reference sugars for identification; mannitol was used as an internal standard. Free sugar content was expressed as $\mathrm{g} / 100 \mathrm{~g}$ sample.

\section{Color measurement}

$\mathrm{L}^{*}$ (lightness), $\mathrm{a}^{*}$ (redness, + or greenness, - ), and $\mathrm{b}^{*}$ (yellowness, + or blueness, - ) values of kochujang were measured using a chroma meter (CR-300; Minolta Corp., Osaka, Japan). A Minolta calibration plate $(\mathrm{YCIE}=94.5, \mathrm{XCIE}=0.3160, \mathrm{YCIE}=0.330)$ and a Hunter Lab standard plate $\left(\mathrm{L}^{*}=97.51, \mathrm{a}^{*}=-0.18\right.$, $\left.b^{*}=+1.67\right)$ were used to standardize the instrument using a D65 illuminant (Kim et al, 2014). Color values were measured directly from 3 zones of peach kochujang and mean values were calculated.

\section{Evaluation of sensory properties}

Samples were rated for taste, color, flavor, and overall taste using scale of $1=$ dislike very much, 2=dislike moderately, 3=dislike slightly, 4=neither like nor dislike, 5=like slightly, 6=like moderately, $7=$ like very much. All the sensory properties were evaluated by 20 volunteer panelists ( 10 women and 10 men) selected from the list of graduate students of College of Food Technology of Kyungpook National University, Daegu, Korea. Mean values of 10 evaluations for each sensory property were reported as scores.

\section{Statistical analysis}

Data were subjected to analysis of variance using the SAS version 9.2 (SAS Institute Inc., Cary, NC, USA). Differences between means at $\mathrm{p}<0.05$ were analyzed using Tukey test

\section{Results and Discussion}

\section{pH, total acid, and reducing sugar contents}

The $\mathrm{pH}$ value and total acid and reducing sugar contents of kochujang are shown in Table 2. The $\mathrm{pH}$ value of three kochujang samples were not significantly different. However, total acid value of PK-3 was significantly high as compared to two other samples. Total acid and amino nitrogen contents of kochujang samples were in order of PK-3>PK-2>PK1. Reducing sugar content of PK-2 (31.51\%) was the highest followed by that of PK-3 (29.35\%). The significant variation in the physicochemical characteristics among kochujang samples might be due the addition of salt replacement, which was prepared with fermented vegetables and brown-rice vinegar. Sweetness of peach kochujang could be modified with the use of salt replacement as the reducing sugar is a main contributor to kochujang sweet taste (Seo et al., 2014). Addition of salt replacement could enhance the taste of peach kochujang since it increased the amino-type nitrogen, which increases the taste of kochujang (Seo et al., 2014). High total acid value of PK-3 might be due to higher total acid content of rice vinegar (Chen et al., 2012) than that of ordinary salt. 
Table 2. Physicochemical characteristics of peach kochujang

\begin{tabular}{lcccc}
\hline Sample $^{1)}$ & $\mathrm{pH}$ & $\begin{array}{c}\text { Total acid }^{2)} \\
(\%)\end{array}$ & Reducing sugar $(\%)$ & $\begin{array}{c}\text { Amino nitrogen } \\
(\mathrm{mg} / \mathrm{g})\end{array}$ \\
\hline PK-1 & $5.02 \pm 0.05^{\mathrm{a} 3)}$ & $5.61 \pm 0.01^{\mathrm{c}}$ & $24.82 \pm 0.20^{\mathrm{c}}$ & $68.60 \pm 9.90^{\mathrm{b}}$ \\
PK-2 & $5.02 \pm 0.04^{\mathrm{a}}$ & $6.14 \pm 0.01^{\mathrm{b}}$ & $31.51 \pm 0.05^{\mathrm{a}}$ & $75.60 \pm 0.00^{\mathrm{b}}$ \\
PK-3 & $5.01 \pm 0.02^{\mathrm{a}}$ & $7.62 \pm 0.07^{\mathrm{a}}$ & $29.35 \pm 0.26^{\mathrm{b}}$ & $82.60 \pm 0.00^{\mathrm{a}}$ \\
\hline
\end{tabular}

${ }^{1)}$ Sample are defined in Table 1.

${ }^{2)}$ As malic acid.

${ }^{3)}$ Quoted values are means \pm SD of triplicate measurements. Values followed by different superscripts in the same column are significantly different $(\mathrm{p}<0.05)$.

\section{Salinity and sodium contents}

The salinity value and sodium content of PK-3 (4.13\% and $1292.26 \mathrm{mg} / 100 \mathrm{~g}$ ) were significantly low as compared to PK-1 (4.21\% and $1568.71 \mathrm{mg} / 100 \mathrm{~g}$ ), respectively (Table 3 ). Low sodium content in PK-3 might be due to substitution of ordinary salt with salt replacement. Thus high quality Kochujang could be prepared by using salt replacement as intake of more sodium may cause aggravation of heart and kidney's burden, leading to high blood pressure and heart diseases (Meneton et al., 2005).

Table 3. Sodium values in peach kochujang

\begin{tabular}{lcc}
\hline Sample $^{1)}$ & Salinity $(\%)$ & Sodium content $(\mathrm{mg} / 100 \mathrm{~g})$ \\
\hline PK-1 & $\left.4.21 \pm 0.01^{\mathrm{a} 2}\right)$ & $1568.71 \pm 189.20^{\mathrm{a}}$ \\
PK-2 & $4.20 \pm 0.01^{\mathrm{a}}$ & $1358.33 \pm 210.94^{\mathrm{ab}}$ \\
PK-3 & $4.13 \pm 0.01^{\mathrm{b}}$ & $1292.26 \pm 125.12^{\mathrm{b}}$ \\
\hline
\end{tabular}

${ }^{\text {I) }}$ Sample are defined in Table 1.

${ }^{2)}$ Quoted values are means \pm SD of triplicate measurements. Values followed by different superscripts in the same column are significantly different $(\mathrm{p}<0.05)$.

\section{Color values and free sugar content}

Color of kochujang is important factor for consumer preference. The L-value (lightness) and a-value (redness) of kochujang samples were significantly decreased, however, the b-value (yellowness) was increased with the addition of salt replacement to substitute ordinary salt (Table 4). Addition of salt substitute showed a tendency to increase a lighter yellow shade as compared to that with ordinary salt containing kochujang. Park and Kim (2007) reported to have increased a- and b-values during fermentation while adding anti-microbial materials to kochujang. In the present study b-value was increased with the addition of salt substitute indicating the color of kochujang could be developed a little similar to that of fermented one.

Table 4. Hunter color values of peach kochujang

\begin{tabular}{lccc}
\hline Sample $^{1)}$ & \multicolumn{3}{c}{ Color value $^{2)}$} \\
\cline { 2 - 4 } PK-1 & $\mathrm{L}^{*}$ & $\mathrm{a}^{*}$ & $\mathrm{~b}^{*}$ \\
PK-2 & $27.08 \pm 1.70^{\mathrm{a} 3)}$ & $8.74 \pm 0.29^{\mathrm{a}}$ & $2.49 \pm 0.78^{\mathrm{c}}$ \\
PK-3 & $25.69 \pm 0.31^{\mathrm{b}}$ & $8.24 \pm 0.16^{\mathrm{b}}$ & $2.79 \pm 0.50^{\mathrm{b}}$ \\
\hline
\end{tabular}

${ }^{1)}$ Sample are defined in Table 1.

${ }^{2)} \mathrm{L}^{*}$, lightness (100, white; 0, black); a*, redness (-, green; +, red); $b^{*}$, yellowness (-, blue; +, yellow).

${ }^{3)}$ Quoted values are means \pm SD of triplicate measurements. Values followed by different superscripts in the same column are significantly different $(p<0.05)$.

Fructose, glucose, and maltose were the major free sugars found in the kochujang samples (Table 5). Levels of fructose and glucose were increased, however that of maltose was not significantly affected by substituting the ordinary salt with salt replacement. Major free sugar in peach kochujang in the present study was maltose. Maltose was also the major free sugar in the kochujang prepared with 
apple and persimmon (Jeong et al., 2000). Glucose, fructose, and maltose are the major free sugars, which are resulted from amylolytic enzymes of

microorganisms in kochujang (Lee and Kim, 1991; Kim et al., 1994).

Table 5. Free sugar content (g/100 g) of peach kochujang

\begin{tabular}{lcccc}
\hline Sample $^{1)}$ & Fructose & Glucose & Sucrose & Maltose \\
\hline PK-1 & $6.60 \pm 0.00^{\mathrm{b} 2)}$ & $11.11 \pm 0.03^{\mathrm{b}}$ & ND $^{3)}$ & $15.10 \pm 0.00^{\mathrm{a}}$ \\
PK-2 & $10.81 \pm 0.30^{\mathrm{a}}$ & $12.89 \pm 0.16^{\mathrm{a}}$ & ND & $16.24 \pm 5.99^{\mathrm{a}}$ \\
PK-3 & $10.55 \pm 0.41^{\mathrm{a}}$ & $13.31 \pm 0.22^{\mathrm{a}}$ & ND & $15.61 \pm 1.30^{\mathrm{a}}$ \\
\hline
\end{tabular}

${ }^{\mathrm{T}}$ Sample are defined in Table 1.

${ }^{2)}$ Quoted values are means \pm SD of triplicate measurements. Values followed by different superscripts in the same column are significantly different $(p<0.05)$.

${ }^{3)} \mathrm{ND}$ : Non detected.

\section{Antioxidant properties}

DPPH and ABTS radical scavenging properties of Kochujang prepared with salt replacement (30.13 and $27.31 \%$ ) were significantly high compared to that prepared with ordinary salt $(27.05$ and $24.72 \%$, respectively) (Table 6). High antioxidant potential for Kochujang prepared with salt replacement might be due to the vegetables present in it as vegetables are rich in antioxidants (Cho et al., 2017).

Table 6. DPPH and ABTS radical scavenging activity of peach Kochujang

\begin{tabular}{lcc}
\hline Sample $^{1)}$ & DPPH (\% Inhibition $)$ & ABTS (\% Inhibition) \\
\hline PK-1 & $27.05 \pm 0.56^{\mathrm{c} 2}$ & $24.72 \pm 0.51^{\mathrm{b}}$ \\
PK-2 & $33.12 \pm 0.21^{\mathrm{a}}$ & $24.69 \pm 0.31^{\mathrm{b}}$ \\
PK-3 & $30.13 \pm 1.01^{\mathrm{b}}$ & $27.31 \pm 1.02^{\mathrm{a}}$ \\
\hline
\end{tabular}

${ }^{1)}$ Sample are defined in Table 1.

${ }^{2)}$ Quoted values are means \pm SD of triplicate measurements. Values followed by different superscripts in the same column are significantly different $(p<0.05)$.

\section{Sensory characteristics}

Evaluation of sensory characteristics of kochujang sample is shown in Table 7. The scores for taste (4.63), flavor (4.88), and color (5.38) were significantly high for kochujang prepared with salt replacement and consequently the overall acceptance (4.81) of the sample was also high as compared to those of kochujang prepared with ordinary salt $(2.81$, $2.94,2.13$, and 3.13, respectively). Addition of salt replacement, which was prepared with fermented vegetables and vinegar, was likely the reason of the high evaluation in terms of taste, flavor, color, and overall acceptance.

Table 7. Sensory characteristics of peach kochujang

\begin{tabular}{lcccc}
\hline \multirow{2}{*}{ Sample $^{1)}$} & \multicolumn{4}{c}{ Sensory characteristics } \\
\cline { 2 - 4 } & Taste & Flavor & Color & Overall acceptance \\
\hline PK-1 & $2.81 \pm 0.86^{\mathrm{c} 2)}$ & $2.94 \pm 0.58^{\mathrm{c}}$ & $2.13 \pm 0.78^{\mathrm{c}}$ & $3.13 \pm 0.70^{\mathrm{c}}$ \\
PK-2 & $3.59 \pm 1.16^{\mathrm{b}}$ & $4.03 \pm 0.76^{\mathrm{b}}$ & $3.97 \pm 1.28^{\mathrm{b}}$ & $4.00 \pm 4.47^{\mathrm{b}}$ \\
PK-3 & $4.63 \pm 1.41^{\mathrm{a}}$ & $4.88 \pm 0.78^{\mathrm{a}}$ & $5.38 \pm 1.22^{\mathrm{a}}$ & $4.81 \pm 0.63^{\mathrm{a}}$ \\
\hline
\end{tabular}

${ }^{1)}$ Sample are defined in Table 1.

${ }^{2)}$ Quoted values are means \pm SD of triplicate experiments $(n=20)$ based on 7 point scores $(1$, dislike very much; 2 , dislike moderately; 3 , dislike slightly; 4 , neither like nor dislike; 5 , like slightly; 6 , like moderately; 7 , like very much). Values followed by different superscripts in the same column are significantly different $(p<0.05)$.

\section{Conclusion}

Peach kochujang was prepared using ordinary salt

(OS) or substituting it with salt replacement (SR) in part or whole. Reducing sugar and amino-type nitrogen contents of SR kochujang were significantly high compared to OS kochujang, however, sodium 
content was significantly low in SR kochujang. Similarly, antioxidant potentials were significantly high for SR kochujang. In addition, overall acceptance score of SR kochujang was higher than that of OS kochujang. The present study showed that substitution of ordinary salt with low sodium containing SR could be possible to prepare nutritious kochujang having significantly high antioxidant potentials.

\section{Conflict of interest}

The authors declare no conflict of interest.

\section{Acknowledgements}

This work was supported by grants from the [RDA Research Program (PJ012004), 'The development of low salted Korean sauces in peach'] through the provincial government in North Gyeongsang, funded by the Rural Development Administration, Republic of Korea.

\section{References}

1) AOAC. 1984. Official Methods of Analysis, $14^{\text {th }}$ ed. Association of Official Analytical Chemists: Washington, DC.

2) Blois MS. 1958. Antioxidant determinations by the use of a stable free radical. Nature. 181: 1199-2000 http://dx.doi.org/10.1038/1811199a0

3) Chen Q, Ding J, Cai J, Sun Z, Zhao J. 2012. Simultaneous measurement of total acid content and soluble salt-free solids content in Chinese vinegar using near-infrared spectroscopy. Journal of Food Science. 77: C222-C227. http://dx.doi.org/10.1111/j.1750-3841.2011.02549.x

4) Cho HO, Kim JG, Lee HJ, Kang JH, Lee TS. 1981. Brewing method and composition of traditional kochujang (red pepper paste) in Junrabook-do area. Journal of Korean Agricultural Chemical Society. 24: 21-28.

5) Cho M, Lee HJ, Kang MH, Min H. 2017. Comparison of antioxidant activity and prevention of lymphocyte DNA damage by fruit and vegetable juices marketed in Korea. Journal of Nutrition and Health. 50: 1-9.

6) Génard M, Souty M. 1996. Modeling the peach sugar contents in relation to fruit growth. Journal of the American Society for Horticultural Science. 121: 1122-1131. http://dx.doi.org/10.17660/actahortic. 1996.416.14

7) Ghose TK. 1987. Measurement of cellulose activities. Pure and Applied Chemistry. 59: 257-258. http://dx.doi.org/10.1351/pac198759020257

8) Hyun KU, No JD, Lim SI, Cha SK, and Choi SY. 2007. Characteristics and HMG -Co A reductase inhibitory activity of fermented red pepper soybean paste (kochujang) prepared from red-rice and barley. Korean Journal of Microbiology and Biotechnology. 35: 173-176.

9) Jeong YJ, Seo JH, Lee GD, Lee MH, Yoon SR. 2000. Changes in quality characteristics of traditional kochujang prepared with apple and persimmon during fermentation. Korean Society of Food Science and Nutrition. 29: 575-581.

10) Kim DH, Lee JS. 2001. Effect of condiments on the physicochemical characteristics of traditional kochujang during fermentation. Korean Journal of Food Science and Technology. 33: 353-360.

11) Kim DH, Yang SE. 2004. Fermentation characteristics of low salted kochujang prepared with sub-materials. Korean Journal of Food Science and Technology. 36: 97-104.

12) Kim DH. 2001. Effect of condiments on the microflora, enzyme activities and taste components of traditional kochujang during fermentation. Korean Journal of Food Science and Technology. 33: 264-270.

13) Kim DH. 2005. Fermentation characteristics of low salted kochujang prepared with mixture of sub-materials. Korean Journal of Food Science and Technology. 37: 449-455.

14) Kim ID, Lee JW, Kim SJ, Cho JW, Dhungana SK, Lim YS, Shin DH. 2014. Exogenous application of natural extracts of persimmon (Diospyros kaki Thunb.) can help in maintaining nutritional and mineral composition of dried persimmon. African Journal of Biotechnology. 13: 2231-2239. http://dx.doi.org/10.5897/ajb2013.13503

15) Kim YS, Kwon DJ, Oh HI, Kang TS. 1994. Comparison of physicochemical characteristics of traditional and commercial kochujang during fermentation. Korean Journal of Food Science and Technology. 26: 12-17.

16) Kim YS, Oh BH, Shin DH. 2008. Quality characteristics of kochujang prepared with different meju fermented with Aspergillus sp. and Bacillus subtilis. Food Science and Biotechnology. 3: 527-533.

17) Kim YS, Song GS. 2002. Characteristics of fig-added traditional kochujang. Food Science and Biotechnology. 11: 673-679.

18) Kwon DY, Chung KR, Yang HJ, Jang DJ. 2015. Gochujang (Korean red pepper paste): a Korean ethnic sauce, its role and history. Journal of Ethnic Foods. 2: 29-35.

19) Kwon DY, Jang DJ, Yang HJ, Chung KR. 2014. History of Korean gochu, gochujang, and kimchi. Journal of Ethnic Foods. 1: 3-7.

20) Lee HS. 1997. Studies on salt intake through eat-out foods in Andong area. Korean Journal of Society of Food Science. 13: 314-318.

21) Lee JH. 2008. Effect of Prunus mume extract on the physicochemical properties of Korean hot pepper-soybean paste. Food Engineering Progress. 12: 128-132.

22) Lee KS, Kim DH. 1991. Effect of sake cake on the quality of low salted kochuzang. Korean Journal of Food Science and Technology. 23: 109-115.

23) Lee TS. 1979. Studies on the brewing of kochujang (red pepper paste) by the addition of yeasts. Journal of Korean Agricultural Chemical Society. 22: 65-90.

24) Meneton $P$, Jeunemaitre $X$, de Wardener HE, Macgregor GA. 2005. Links between dietary salt intake, renal salt handling, blood pressure, and cardiovascular diseases. Physiological Reviews. 85: 679-715. http://dx.doi.org/10.1152/physrev.00056.2003

25) Moon TW, Kim ZU. 1988. Some chemical physical characteristics and acceptability of kochujang from various starch sources. Journal of the Korean Agricultural Chemical Society. 31: 387-393.

26) Oh HI, Shon SH, Kim JM. 2000. Physicochemical properties of kochujang prepared with Aspergillus oryzae, Bacillus licheniformis and Saccharomyces rouxii during fermentation. Journal of Korean Society of Food Science and Nutrition. 29: 357-363.

27) Oh JY, Kim YS, Shin DH. 2002. Changes in physicochemical characteristics of low-salted kochujang with natural preservatives during fermentation. Korean Journal of Food Science and Technology. 34: 835-841.

28) Oh JY, Kim YS, Shin DH. 2006. Changes in microorganisms, enzyme activities, and gas formation by the addition of mustard powder on kochujang with different salt concentration. Food Science and Biotechnology. 15: 298-302

29) Park SJ, Kim DH. 2007. Effect of combined use of various anti-microbial materials on brewing of low salted kochujang. Journal of Korean Society of Applied Biological Chemistry. 50: 287-294.

30) Re R, Pellegrini N, Proteggente A, Pannala A, Yang M, RiceEvans C. 1999. Antioxidant activity applying an improved ABTS radical cation decolorization assay. Free Radical Biology and Medicine. 26: 1231-1237. http://dx.doi.org/10.1016/s0891-5849(98)00315-3 
31) Seo YE, Bae HS, Kim DH. 2014. Effect of the addition of antimicrobial materials before and after aging on the physicochemical properties of low-salt kochujang during storage. Journal of Applied Biological Chemistry. 57: 287294.

32) Shin DH, Ahn EY, Kim YS, Oh JA. 2000. Fermentation characteristics of kochujang containing horseradish or mustard. Korean Journal of Food Science and Technology. 32. 1350-1357.

33) Shin DH, Kim DH, Choi U, Lim MS, An EY. 1997. Physicochemical characteristics of traditional kochujang prepared with various raw materials. Korean Journal of Food Science and Technology. 29: 907-912.

34) Shin DH, Kwon DY, Kim YS, Jung DY. 2011. Science and Technology of Gochujang. Bogunedu, Seoul, Korea.

35) Shin EK, Lee YK. 2014. Comparison of sodium content of workplace and homemade meals through chemical analysis and salinity measurements. Nutrition Research and Practice. 8: 558-563.

36) Yamamoto Y, Higashi K, Yoshii H. 1984. Inhibitory activity of ethanol on food spoilage bacteria. Nippon Shokuhin Kogyo Gakkaishi. 31: http://dx.doi.org/10.3136/nskkk1962.31.8_531 